Łukasz Mirocha

Uniwersytet Mikołaja Kopernika w Toruniu

\title{
Globalna sprawiedliwość a problem imigracji
}

DOI: $10.19195 / 1643-0328.23 .3$

Słowa kluczowe: globalna sprawiedliwość, liberalizm, komunitaryzm, imigracja, problem gapowicza

\section{Wprowadzenie}

Imigracja mieszkańców Bliskiego Wschodu oraz północnej Afryki do Europy jest tematem nieustających dyskusji zarówno w dyskursie publicznym, jak i naukowym. Problem ten dotyka dziedzin etyki, filozofii, prawa. Opinię publiczną oraz fora organów państwowych i tych na szczeblu Unii Europejskiej elektryzują liczby. Nie gasną spory odnośnie do liczby imigrantów mających znaleźć pomoc w Polsce i innych krajach, padają pytania o to, jakiej wysokości środki winny być przeznaczane na ich utrzymanie, z czyjego budżetu. Prezentowane są spolaryzowane stanowiska: od entuzjastycznych, często odwołujących się do argumentu "nam pomagano, więc my również jesteśmy zobowiązani pomóc” bądź wprost apelujących do miłosierdzia, przez sceptyczne - skupiające się na braku możliwości po stronie przyjmujących udzielenia efektywnej pomocy i na faktycznym narzuceniu przez UE liczby imigrantów wbrew woli obywateli poszczególnych państw ${ }^{1}$, aż po ksenofobiczne, podkreślające odmienności kulturowe, religijne czy etniczne przyjmujących i imigrantów oraz mogące z tego wyniknąć negatywne konsekwencje.

Z perspektywy filozoficznej za problemami tymi kryje się bardziej zasadnicza kwestia: Czy, a jeśli tak, to dlaczego państwa, narody, mieszkańcy Europy winni udzielać wsparcia imigrantom? Przekładając te pytania na język dominujący we współczesnej filozofii prawa i polityki, otrzymamy pytanie o podstawy globalnej czy ponadnarodowej sprawiedliwości ${ }^{2}$, globalnego zarządzania i wynikające $\mathrm{z}$ nich obowiązki. W artykule podejmuję problem globalnej sprawiedliwości, prezentując niektóre, obecne we współczesnej filozofii prawa i polityki, kierunki rozważań z tego zakresu oraz ukazuję kil-

${ }^{1}$ Co przypomina o ciągle aktualnym dla UE problemie „deficytu demokracji”, por. W. Kymlicka, Wspótczesna filozofia polityczna, Warszawa 2009, s. 379-383.

2 W kwestiach terminologicznych: M. Soniewicka, Sprawiedliwość globalna - przegląd wybranych zagadnień, http://www.incet.uj.edu.pl/dzialy.php?l=pl\&p=32\&i=1\&m=22\&z=0\&n=2\&k=13 (dostęp: 12 września 2015). 
ka związanych z nimi paradoksów. Uznając fakt istnienia państw, porównuję postulaty zwolenników globalnej sprawiedliwości z filozoficznymi uzasadnieniami podstawowych podejść do polityki imigracyjnej. Proponuję wykorzystanie zaczerpniętej z nauk ekonomicznych konstrukcji „gapowicza” (ang. free-rider problem) na płaszczyźnie polityki imigracyjnej (czyli „dystrybucji przynależności”) jako kryterium komplementarnego względem postulatów globalnej sprawiedliwości. W konkluzji próbuję ocenić postawę UE wobec imigrantów przy wykorzystaniu tak skonstruowanego pryzmatu.

\section{Czy? Co? Dlaczego? I komu jesteśmy winni?}

Opracowania dotyczące globalnej sprawiedliwości bardzo często otwiera, a prawie zawsze zawierają one w swej treści, przytoczenie sugestywnych danych statystycznych dotyczących ubóstwa na świecie i dysproporcji w dochodach mieszkańców globu. Punktem stale w nich obecnym jest wyliczenie, ilu ludzi żyje aktualnie za mniej niż 2 dolary dziennie (według parytetu siły nabywczej) czy jaka liczba państw odpowiada za wytworzenie określonego odsetka światowego dochodu ${ }^{3}$. Takie podejście do tematu sugeruje, że teorie globalnej sprawiedliwości będą teoriami sprawiedliwości dystrybutywnej, których przedmiotem zainteresowania będzie niwelowanie różnic w poziomie bogactwa. Jest to poniekąd słuszna intuicja, jednakże, jak pokażą dalsze rozważania, szereg teorii globalnej sprawiedliwości abstrahuje od redystrybucji dóbr na poziomie globalnym, a nawet ją potępia.

Poszukując trafnej definicji globalnej sprawiedliwości, tj. dostatecznie szerokiej, by mieściły się w niej zarówno stanowiska dystrybucyjne, jak i te nazywające globalną dystrybucję dóbr "mrzonką"4, zacznijmy od wykluczenia kilku propozycji. W pojęciu globalnej sprawiedliwości nie będzie mieściła się teoria zwana realizmem bądź statyzmem $^{5}$, której węzłową zasadą jest odrzucenie wszelkich względów moralnych w polityce międzynarodowej $\mathrm{i}$ kierowanie się w tej sferze wyłącznie interesem państwa $\mathrm{i}$ jego siłą $^{6}$. Teoria ta znajduje oparcie $\mathrm{w}$ klasycznym pojmowaniu suwerenności państwowej, które zdaniem części badaczy staje się coraz bardziej archaiczne i nieadekwatne ${ }^{7}$, co łą-

${ }^{3}$ Np. J. Mandle, Globalna sprawiedliwość, Warszawa 2009, s. 126 n.; V. Zanetti, Equality or a minimal standard in global justice?, „European Journal of Law Reform” 6, 2004, nr 3-4, s. 397; M. Kuniński, Sprawiedliwość globalna: szlachetny ideat czy rzetelna teoria?, „Diametros” grudzień 2010, nr 26, s. 145.

${ }^{4}$ Już w tym momencie warto zasygnalizować, że większość teorii globalnej sprawiedliwości będzie można zaetykietować jako dystrybucyjno-egalitarne bądź, w opozycji do nich, jako teorie minimalnych standardów, por. V. Zanetti, op. cit., s. 398 n. Krytycznie na temat tego rozróżnienia pisze Wojciech Sadurski (Teoria sprawiedliwości. Podstawowe zagadnienia, Warszawa 1988, s. 51 n.).

${ }^{5}$ Inaczej statyzm postrzega Marta Soniewicka, traktując tę koncepcję jako typ wielopoziomowej, tj. rozróżniającej obowiązki względem osób przynależących do naszej wspólnoty i innych, sprawiedliwości globalnej i uznając Prawo ludów J. Rawlsa za przykład statyzmu - eadem, Granice sprawiedliwości, sprawiedliwość ponad granicami, Warszawa 2010, s. 235-261.

6 J. Mandle, op. cit., s. 40-49.

7 L. Morawski, Suwerenność i prawo międzynarodowe - od prawa państw do prawa ludów, „Forum Prawnicze” styczeń 2011, nr 1 (3), s. 22. Odnośnie do anachroniczności argumentacji realistów - M. Soniewicka, Granice sprawiedliwości..., s. 73. 
czy się także z wzrostem praktycznego znaczenia na arenie międzynarodowej postulatów globalnej sprawiedliwości. Można zaryzykować tezę, że koncepcją sprawiedliwości wewnętrznej, najbardziej zbliżoną do statyzmu w sferze ponadpaństwowej, jest libertarianizm, jako że odrzuca on obowiązek pomocy innym, pod warunkiem że zapewniony jest uczciwy system wymiany między podmiotami ${ }^{8}$. Z pola rozważań powinniśmy moim zdaniem wyłączyć także argumenty odwołujące się raczej do uczuć, np. miłosierdzia, niż do rozumu, mimo że sztywne rozdzielenie tych sfer, tak oczywiste dla intelektualnych spadkobierców Kanta, bywa zasadnie kwestionowane przez ich antagonistów ${ }^{9}$. Jak stwierdza Nigel Dower, mówiąc o miłosierdziu, myślimy w kategoriach naszego indywidualnego obowiązku (a często nawet nie obowiązku, lecz prawa do jego okazania), tymczasem „idea sprawiedliwości obejmuje nie tylko to, co czynią jednostki, lecz także ogólne struktury i stosunki, jakie istnieją lub powinny istnieć w społeczeństwie"10.

Dysponując tak zawężoną płaszczyzną rozważań, można przejść do pytania o to, co sprawiło, że globalna sprawiedliwość stała się w ogóle przedmiotem zainteresowania prawników i filozofów. Przyjmuje się, że oczy badaczy zwróciły się w kierunku sprawiedliwości globalnej w latach 90. XX w. ${ }^{11}$, jednakże pewne antecedencje postawy zbliżonej do sprawiedliwości globalnej obserwuje się już u starożytnych stoików ${ }^{12}$. Jeden ze składników ich myśli - uznanie równej wartości moralnej wszystkich jednostek ludzkich (uniwersalizm etyczny) - utorował drogę do namysłu nad globalną sprawiedliwością ${ }^{13}$. Kolejne dwa czynniki wiążą się z globalizacją, konkretnie jej aspektami: ekonomicznym oraz technologiczno-informacyjnym. Pierwszy z aspektów to tworzenie międzynarodowych powiązań handlowych oraz organizacji i porozumień mających te powiązania regulować (WTO, Bank Światowy, Międzynarodowy Fundusz Walutowy, GATT, TRIPS); mówiąc o drugim, mam na myśli nieosiągalną wcześniej swobodę i prędkość przepływu informacji. O ile ekonomiczny aspekt globalizacji w dużej mierze przyczynił się do powstania bądź pogłębienia dysproporcji w rozwoju i bogactwie poszczególnych państw ${ }^{14}$,

8 Por. N. Dower, Nędza na świecie, [w:] Przewodnik po etyce, red. P. Singer, Warszawa 2009, s. 322. Podkreślam jednak ryzykowność tej tezy, zwłaszcza z uwagi na ignorowanie przez Realpolitik (i posługujące się nią bogate państwa Zachodu) warunku uczciwej wymiany, np. poprzez prowadzenie polityki celnej czy dotacji dla rolnictwa preferujących swoich wytwórców. Na temat warunków uczciwej wymiany międzynarodowej por. F.J. Garcia, Three takes on global justice, „University of La Verne Law Review” 31, 2009-2010, s. 349 n. Możliwości traktowania libertarianizmu jako teorii globalnej sprawiedliwości rozważa Marta Soniewicka - eadem, Granice sprawiedliwości..., s. 154-178.

9 Por. R. Rorty, Filozofia jako polityka kulturalna, Warszawa 2009, s. 82 n.

10 N. Dower, op. cit., s. 316.

11 J. Mandle, op. cit., s. 10.

12 M. Kuniński, op. cit., s. 137.

13 Zastrzec jednak trzeba, iż w literaturze kwestionowane bywa twierdzenie, że z uznania równości moralnej wszystkich ludzi wynikają obowiązki w sferze ponadnarodowej, np. wobec przedstawicieli innych narodowości. W tym kierunku, odnośnie do obowiązku redystrybucyjnego, E.B. Foley, The elusive quest for global justice, „Fordham Law Review” 66, 1997-1998, s. 249.

14 J. Mandle, op. cit., s. 151-178. Nie można oczywiście zapominać o innych czynnikach wpływających na ten stan, które Rawls nazywa zbiorczo „obciążeniem niekorzystnymi warunkami”, takimi jak „brak politycznej i kulturalnej tradycji, kapitału ludzkiego i know-how”, zasobów technologicznych czy naturalnych - por. idem, Prawo ludów, Warszawa 2001, s. 154 n. 
o tyle rewolucja informatyczna pozwoliła wszystkim jej beneficjentom obserwować, a przez to uświadamiać sobie, z jakimi problemami borykają się ludzie oddaleni od nich o tysiące kilometrów, oraz problemy globalne, będące udziałem jednych i drugich (np. zmiany klimatyczne, broń masowego rażenia, terroryzm). W tym kontekście mówi się o „wspólnocie wiedzy” i globalnym „społeczeństwie ryzyka”, sprostanie tym problemom nie leży bowiem w zasięgu któregokolwiek pojedynczego państwa ${ }^{15}$.

Ostatnia uwaga, zanim przejdę do odpowiedzi na zawarte w tytule tej części artykułu pytania. Pojawienie się w nauce rozważań na temat globalnej sprawiedliwości wynikało oczywiście z obserwacji, że dotychczas opracowane teorie sprawiedliwości nie dają się w prosty sposób rozciągnąć na skalę światową, były skrojone na miarę państw ${ }^{16}$. Autor najbardziej wpływowej liberalno-egalitarnej teorii sprawiedliwości - John Rawls - wprost odrzuca możliwość objęcia sprawiedliwością dystrybutywną globu (mimo że stojące u podstaw jego teorii uniwersalistyczne założenia wręcz predestynowały ją do zajęcia tego miejsca $)^{17}$. Michael Walzer oraz Michael Sandel jako filozofowie tworzący w opozycji do Rawlsa, tym razem zgodnie z jego przekonaniami, wskazują, iż realizacja sprawiedliwości możliwa jest co najwyżej w ramach państwa ${ }^{18}$. Niemniej duża część teorii globalnej sprawiedliwości jest kalką ${ }^{19}$, rzadziej rozwinięciem ${ }^{20}$, kontraktualnego podejścia Rawlsa lub w jakiś sposób nawiązuje do myśli komunitarystów ${ }^{21}$.

Na pierwsze z pytań - „Czy jesteśmy coś winni?” — odpowiedź już pośrednio padła, wykluczyliśmy bowiem z grona teorii globalnej sprawiedliwości te, które dają na nie odpowiedź negatywną. Wspólnym wątkiem wszelkich teorii globalnej sprawiedliwości jest uznanie, iż jesteśmy w jakiś sposób zobligowani względem pozostałych mieszkańców Ziemi. Realizm negujący te zobowiązania jest teorią coraz bardziej przebrzmiałą, przynajmniej w kręgu państw Zachodu, uznających za ius cogens prawa międzynarodowego poszanowanie praw człowieka ${ }^{22}$.

Nieco dłużej należy zatrzymać się przy pytaniu „Co jesteśmy winni innym mieszkańcom globu?”, które łączyło się będzie z pytaniem „Komu konkretnie jesteśmy coś winni i dlaczego?". Jak sygnalizowałem wyżej, badacze sugerują dwa zasadnicze rozwiązania tego problemu. Pierwsze z nich to prowadzenie globalnej egalitarnej polity-

15 F.J. Garcia, op. cit., s. 324, 341-342.

16 L. Henkin, An immigration policy for just society?, „San Diego Law Review” 31, 1994, s. 1017.

17 Por. J. Rawls, op. cit., s. 168 n.

18 Odpowiednio: M. Walzer, Sfery sprawiedliwości. Obrona pluralizmu i równości, Warszawa 2007, s. 61; M. Sandel, Sprawiedliwość. Jak postępować słusznie?, Warszawa 2013, s. 297, 309 n.

19 Np. G. Brock, Basic liberties and global justice, „Canadian Journal of Law and Jurisprudence” 19, 2006, nr 2, gdzie autorka przedstawia sytuację pierwotną Rawlsa jako konferencję delegatów z poszczególnych państw (s. 281), a jej argumenty, np. odpowiedź ludziom nieceniącym autonomii osobistej, lecz przywiązanie do tradycji (s. 287), przypominają kopię tez Rawlsa z Liberalizmu politycznego (Warszawa 1998, por. zwłaszcza s. 415-421).

20 J. Mandle, op. cit.; R. Vernon, Contractualism and global justice: The iteration provisio, „Canadian Journal of Law and Jurisprudence" 19, 2006, nr 2.

${ }^{21}$ Istotą nawiązujących do komunitaryzmu koncepcji globalnej sprawiedliwości będzie wielopoziomowość, por. przypis 5 oraz M. Soniewicka, Granice sprawiedliwości..., s. 179-205.

22 Por. L. Morawski, op. cit., s. 29. 
ki redystrybucyjnej. Zdaniem autorów z tej grupy winni jesteśmy materialną równość lub przynajmniej dążenie do niej. Rozwiązanie to przedstawiane jest $\mathrm{w}$ dwóch wariantach: jeden z nich zakłada utworzenie ogólnoświatowego państwa, w ramach którego prowadzona byłaby polityka egalitarna, drugi - utrzymanie granic państwowych, ale korzystanie $\mathrm{z}$ instrumentów dystrybucyjnych zbliżonych do podatków, na poziomie międzynarodowym.

Zostawmy na chwilę rozwiązanie w pełni kosmopolityczne, by przyjrzeć się propozycji globalnych podatków. Ich przykładem mogłyby być podatki od wykorzystywanych zasobów naturalnych ${ }^{23}$, transakcji walutowych ${ }^{24}$ lub instytucja Powszechnego Udziału $\mathrm{w}$ Bogactwach $\mathrm{z}$ międzynarodowym funduszem administrującym zgromadzonymi środkami ${ }^{25}$. Pierwsza $\mathrm{z}$ tych propozycji ma tę przewagę nad pozostałymi, że jest nastawiona na niwelację różnic w dochodach wynikających z czynników rzeczywiście przygodnych - np. tego, czy żyjemy w państwie położonym na złożach roponośnych, czy całkowicie pozbawionym bogactw. Wszystkie one dzielą jednak tę podstawową wadę, iż nie są wrażliwe na a mbicję. Co jeśli spośród dwóch państw, startujących z tego samego pułapu, po jakimś czasie jedno przekształca się w supermocarstwo, drugie zaś staje na skraju bankructwa? Czy obowiązek redystrybucji nadal jest aktualny? Taka była historia np. Argentyny i USA ${ }^{26}$. Abstrahując od tej wątpliwości, przeciwnicy dystrybucji zwracają uwagę, że poziom zamożności poszczególnych państw w niewielkim stopniu zależy od ich bogactw naturalnych, decydujące jest urządzenie społeczeństwa, jego kultura polityczna ${ }^{27}$. Autorzy ci sugerują zatem, że ważniejsze jest wykreowanie w społeczeństwach, będących potencjalnymi beneficjentami globalnej sprawiedliwości, właściwej kultury politycznej, niż mechaniczne „wstrzykiwanie” pomocy materialnej, która może zostać zmarnotrawiona, np. przez niedemokratyczny reżim. Jest to istota argumentacji zwolenników teorii minimalnych standardów.

Wróćmy teraz do koncepcji kosmopolitycznej. Podstawowe zarzuty jej stawiane zasadzają się na twierdzeniu, iż globalne państwo po prostu nie istnieje, co więcej, nic nie wskazuje na to, by miało szansę zaistnieć. Z jednej strony, populacja zasiedlająca glob jest zbyt zróżnicowana pod każdym względem, by takie przedsięwzięcie mogło dojść do skutku ${ }^{28}, \mathrm{z}$ drugiej (co jest również zarzutem względem wszystkich teorii globalnej sprawiedliwości) - jaki interes miałyby państwa nieliberalne w przystąpieniu do takiego przedsięwzięcia? ${ }^{29}$ Kolejne zastrzeżenia odnośnie do teorii kosmopolitycznej dotyczą

23 Por. E.B. Foley, op. cit., s. 258 n.

24 Por. J. Mandle, op. cit., s. 163.

25 J. Rawls, Prawo ludów..., s. 173.

26 Por. E.B. Foley, op. cit., s. 253 n.; J. Rawls, Prawo ludów..., s. 170 n. Syntetyczne wyliczenie racji Rawlsa w tym zakresie w: V. Zanetti, op. cit., s. 401.

27 J. Rawls, Prawo ludów..., s. 170.

28 F.J. Garcia, op. cit., s. 326. Walzer, wyrażając swój sceptycyzm, pisze o takim przedsięwzięciu: „Bardzo różnorakie grupy wciąż kształtowałyby życie swoich członków w znaczący sposób, lecz przez władze centralne na ogół traktowane byłyby jak powietrze; nie uwzględniano by partykularystycznych interesów; nie zezwalano by na publiczne wyrażanie różnic kulturalnych" (Spór o wojnę, Warszawa 2006, s. 206).

29 F.J. Garcia, op. cit., s. 337. 
ryzyka wystąpienia w takim globalnym, wszechwładnym państwie tyranii na niespotykaną skalę ${ }^{30}$. Mnożenie kosztów dystrybucji zasobów, które mogłyby znacząco przekraczać pozytywny efekt jej dokonywania (co jest bolączką wszelkich systemów tego typu), jest inną wadą komentowanego rozwiązania.

Powyższe uwagi w zasadzie wyczerpują kwestię tego, kto występuje w roli beneficjentów, a kto uprawnionych. W koncepcjach egalitarnych transfer zasobów następuje od państw bogatych do biednych. Uzasadnieniem tego może być obecna już w Teorii sprawiedliwości Rawlsa zasada dyferencji, nakazująca tak urządzać relacje społeczne, by działały one na rzecz tych w najgorszym położeniu. Nikt bowiem nie powinien ponosić negatywnych konsekwencji okoliczności, na które nie miał wpływu — przygodnych, arbitralnych ${ }^{31}$. Do takich wniosków prowadzą pewne adaptacje myśli wczesnego Rawlsa i utylitaryzm Singera ${ }^{32}$.

Zwolennicy teorii minimalnych standardów, moim zdaniem słusznie, negują opisane założenia w kontekście relacji międzynarodowych. Część ich argumentów padła już wyżej. Dowodzą oni m.in., że poziom zamożności państwa nie musi zależeć od jego zasobów naturalnych, determinuje go kultura polityczna. Wobec tego nie jesteśmy zobowiązani rekompensować nikomu krzywd czy strat będących wynikiem jego własnego wyboru $^{33}$. Co innego, jeśli cudze krzywdy są choćby po części efektem naszego działania, wówczas obowiązek pomocy, choć niekoniecznie, wprowadzenia materialnej równości, istnieje $^{34}$. Stanowisko to wydaje się trafne, niezbędne jest jednak jego zniuansowanie, którego dokonuje Rawls w Prawie ludów. Odróżnia on społeczeństwa dobrze urządzone (liberalne oraz przyzwoite) i społeczeństwa niewłaściwie urządzone, do których zalicza społeczeństwa obciążone, państwa bezprawia i łagodne absolutyzmy. Społeczeństwom obciążonym winni jesteśmy zdaniem Rawlsa pomoc (niepolegającą wszak koniecznie na transferze środków), nie odpowiadają one przecież za warunki, w jakich się znalazły ${ }^{35}$. Istotne jest także, szczególnie w kontekście łagodnych absolutyzmów i rządów bezprawia, odróżnienie państwa, do którego odnoszą się te opisy, od społeczeństw, czy jak je określa Rawls - ludów ${ }^{36}$. Rawls dąży do objęcia swoją myślą właśnie społeczeństw, a nie państw, w których one żyją ${ }^{37}$.

Autor Prawa ludów ogranicza się do skomponowania zasad rządzących ludami dobrze urządzonymi, ich uzasadnienia oraz przedstawienia prawideł „wojny sprawiedliwej” w razie konfliktu z państwami niewłaściwie urządzonymi. Nie budzi wątpliwości, że właściwe urządzenie państw ma być celem godnym dążeń ${ }^{38}$. W jego pracy nie dostrzegam

30 E.B. Foley, op. cit., s. 262.

31 Por. W. Kymlicka, op. cit., s. 97 n.

32 Por. M. Soniewicka, Sprawiedliwość globalna...; N. Dower, op. cit., s. 323-324.

33 E.B. Foley, op. cit., s. 254-255.

34 M. Walzer, Sfery sprawiedliwości..., s. 87.

35 J. Rawls, Prawo ludów..., s. 154 n.

36 Chociaż, jak wskazuje M. Kuniński, różnica ta zamazuje się w kontekście ludów liberalnych — idem, op. cit., s. 152 .

37 Por. L. Morawski, op. cit., s. 24.

38 Por. M. Soniewicka, Sprawiedliwość globalna... 
natomiast wskazówek odnośnie do tego, jak winniśmy realizować obowiązek pomocy, jak uzyskać ten efekt. Odpowiedź znaleźć można u kontynuatora dzieła Rawlsa - Jona Mandlea. Wskazuje on na obowiązek interwencji humanitarnej jako instrument służący ochronie praw człowieka i potencjalnie umożliwiający kreowanie właściwej struktury społecznej ${ }^{39}$. To właśnie prawa człowieka, do których Mandle zalicza również prawo do minimum socjalnego, stanowią „minimalny standard”.

Przemyślmy teraz zarzuty stawiane koncepcji minimalnych standardów. Pozostając przy instrumentach ich wprowadzania, wskazać trzeba niską skuteczność interwencji humanitarnych i kulejące mechanizmy decydowania o ich prowadzeniu. Nie można tracić z pola widzenia faktu, że efektem obalenia opresyjnych reżimów często jest nastanie anarchii, która przynosi stan jeszcze bardziej odległy od ideałów praw człowieka niż władza dyktatorów ${ }^{40}$. Przykładem tego może być stojąca u podstaw aktualnej migracji tzw. Arabska Wiosna. Innym zarzutem kierowanym wobec teorii minimalnych standardów jest uznawanie moralnej istotności tak arbitralnych czynników, jak przynależność państwowa, które rzutują na różnicowanie naszych obowiązków względem krajanów i ob$\mathrm{cych}^{41}$. Uznanie ważności takich czynników może być odbierane jako podważenie istoty koncepcji globalnej sprawiedliwości, którą jest moralna równość wszystkich ludzi. Paradoksalnie jednak uznanie praw człowieka za ius cogens prawa międzynarodowego, a co za tym idzie - przyznawanie coraz szerszego katalogu uprawnień każdemu, niezależnie od jego statutu obywatelskiego (przez niektórych nazywane „postnacjonalizmem”42), może być uznane za realizację postulatów teorii minimalnych standardów.

Dotychczasowe rozważania pozwalają dostrzec, że aktualne stosunki międzynarodowe zbliżają się do koncepcji globalnej sprawiedliwości minimalnych standardów z obszarami objętymi polityką dystrybucyjną. Liczba podmiotów relacji międzynarodowych stale rośnie. Przestają nimi być wyłącznie państwa, coraz aktywniejszą rolę odgrywają organizacje ponadnarodowe i pozarządowe stojące na straży praw człowieka oraz koordynujące transfer środków na rzecz ubogich rejonów świata. Środki te nierzadko pochodzą nie od państw, lecz bezpośrednio od ich obywateli i kierowane są wprost do indywidualnych adresatów (np. tzw. adopcja na odległość), co stawia poszczególne jednostki $\mathrm{w}$ miejscu dotychczasowych stron relacji międzynarodowych. Elementy polityki dystrybucyjnej w wymiarze ponadnarodowym wprowadza z kolei UE. Pluralizm ośrodków ponadnarodowego zarządzania czy koordynacji należy przyjąć $\mathrm{z}$ optymizmem, w ten sposób chronione są lokalne tradycje czy interesy, przy stałej kontroli z perspektywy praw człowieka ${ }^{43}$. Mogą one tworzyć swego rodzaju system wzajemnego check and balance. Pluralizm ten oddala groźbę globalnej tyranii, paternalizmu czy „ideologicznej hegemonii”, przy względnej gwarancji, że któryś z ośrodków zareaguje, gdy pojawi się potrzeba interwencji. Rosnąca sieć powiązań podmiotów różnych szczebli, kształtowa-

39 J. Mandle, op. cit., s. 114 n.

40 Por. J. Gray, Al-Kaida i korzenie nowoczesności, Warszawa 2006, s. 174.

41 Por. na ten temat M. Sandel, op. cit., s. 303-317.

42 Por. K. Banerjee, Toward post-national membership? Tensions and transformation in German and EU citizenship, „Journal of International Law and International Relations” 10, 2014, s. 5-6.

43 Por. M. Walzer, Spór o wojnę..., s. 220-222; G. Brock, op. cit., s. 295-296. 
nie nowych wspólnych praktyk i tradycji sprzyjać będą tworzeniu się wspólnoty globalnej, będącej wspólnotą nie tylko z nazwy ${ }^{44}$. Realizacja ideałów wspólnotowych w sferze globalnej, kosmopolitycznej unicestwi potrzebę namysłu nad globalną sprawiedliwością, jednakże, jak podkreślam, jest to obecnie — odwołując się do słownika Rawlsa rodzaj „realistycznej utopii”.

\section{Globalna sprawiedliwość a problem imigracji}

Udzielanie przez poszczególne państwa ochrony, a nawet obejmowanie nie-obywateli pewnymi dobrodziejstwami welfare state (vide przykład Niemiec i Wielkiej Brytanii), można brać za przejaw postnacjonalizmu i realizowania sprawiedliwości minimalnych standardów. Oderwanie pewnych uprawnień od przynależności państwowej dzieli jednak od postulatów kosmopolityzmu daleka droga. Przykłady zapewniania przez bogate państwa Zachodu, nawet szerokich, udogodnień nie-obywatelom to nadal raczej wyjątek niż reguła, czym innym jest wreszcie ochrona osób legalnie przebywających na terenie kraju, a czym innym zgoda na bezwarunkowe przekraczanie własnych granic. Państwa i dzielące je granice istnieją, co czyni aktualnymi problemy imigracji i „dystrybucji przynależności” ${ }^{45}$, czyli naturalizacji.

Zjawisko imigracji może sprowadzać kwestię sprawiedliwości z forum globalnego na lokalne. Imigracja nie wyklucza jednak zasadniczych dla przeciwników globalnego egalitaryzmu pytań o to, czy zabraniać wstępu do niego obcym oraz czy i dlaczego różnicować mieszkańców danego kraju ze względu na ich przynależność państwową. Warto zauważyć, że wprowadzanie zakazu wstępu do danego państwa na podstawie kryteriów, takich jak pochodzenie czy wykształcenie, w stosunkach wewnętrznych mogłoby zostać łatwo uznane za dyskryminujące ${ }^{46}$. Niemniej jest ono standardem polityki imigracyjnej.

Spróbujmy teraz naszkicować założenia głównych modeli polityki imigracyjnej ${ }^{47}$. Zastrzegam, że modele te raczej noszą cechy ,typu idealnego", niż opisują to, jak faktycznie prowadzona jest polityka imigracyjna. W rzeczywistości obserwujemy dynamiczne zmiany polityki poszczególnych państw zachodzące między tymi modelami, krzyżowanie ich oraz stosowanie pewnych ich elementów względem konkretnych kategorii imigrantów.

Pierwszy model polityki imigracyjnej znajduje uzasadnienie w utylitaryzmie i chęci osiągnięcia lub podtrzymania wzrostu ekonomicznego. Może on polegać na podjęciu działań w celu sprowadzania wykwalifikowanej kadry pracowniczej do kraju (tzw. brain- drain $^{48}$ ) bądź na otwarciu granic dla rzesz „taniej siły roboczej”. Instytucja Niebieskiej Karty wprowadzona przez UE jako ułatwienie dla wykwalifikowanych pracowników

44 F.J. Garcia, op. cit., s. 342.

45 M. Walzer, Sfery sprawiedliwości..., s. 62.

46 L. Henkin, op. cit., s. 1019.

47 W omówieniu korzystam z: J.D. Skrentny, How to understand immigration policy, „Brown Journal of World Affairs" 20, 2013, nr 1, s. 139-152, chyba że wprost odwołuję się do innego źródła.

48 L. Henkin, op. cit., s. 1020. 
spoza jej terytorium to przykład działania polityki utylitarnej w pierwszej wersji. Ilustracją otwartej polityki imigracyjnej wynikającej z potrzeby zapewnienia gospodarce pracowników niewykwalifikowanych były programy sprowadzania tzw. gastarbeiterów, prowadzone w Niemczech, czy przyjmowanie migrantów z byłych kolonii przez Wielką Brytanię i Francję ${ }^{49}$.

Kolejnym popularnym modelem polityki imigracyjnej jest model liberalno-uprawnieniowy, kładący nacisk na traktowanie imigrantów i obywateli jako podmiotów praw. Model ten również występuje $\mathrm{w}$ dwóch odmianach, $\mathrm{z}$ których pierwsza nakazuje władzom państwowym poszanowanie równej godności wszystkich mieszkańców kraju niezależnie od pochodzenia, co odzwierciedla np. polityka łączenia rodzin imigrantów. Druga odmiana przestrzega natomiast przed zbyt otwartą polityką imigracyjną w obawie przed erozją welfare state oraz odbieraniem przez imigrantów miejsc pracy obywate$\operatorname{lom}^{50}$, chroniąc raczej własnych obywateli.

Model tradycyjnej wspólnoty to inny, wciąż aktualny wariant polityki imigracyjnej. Za jego ucieleśnienie można uznać politykę Izraela, restrykcyjnie traktującą przybyszów niemogących wykazać żydowskiego pochodzenia, przy jednoczesnym automatyzmie w nadawaniu obywatelstwa osobom posiadającym żydowskie korzenie. Przejawem tej polityki może być nie tylko budowanie murów granicznych (vide USA-Meksyk, Izrael-państwa ościenne), ale także zakaz budowania minaretów w Szwajcarii czy noszenia burek we Francji.

Analizując wskazane modele z perspektywy globalnej sprawiedliwości, łatwo można dojść do wniosku, że pierwszy i ostatni stoją, w zasadzie, w opozycji do postulatów któregokolwiek z jej wariantów. Utylitaryzm i konserwatywny komunitaryzm (bo w tym nurcie, np. myśli Alasdaira MacIntyre’a, szukać należy filozoficznego uzasadnienia polityki tradycyjnej wspólnoty) kładą nacisk na interesy konkretnej, zamkniętej zbiorowości, czyniąc to jednak $\mathrm{z}$ odmiennych powodów ${ }^{51}$. Model liberalno-uprawnieniowy jest natomiast do pogodzenia z postulatami globalnej sprawiedliwości. Bliska jest mu idea niedzielenia mieszkańców państwa na „obywateli i metojków” ${ }^{2}$ oraz ułatwiania dostępu do obywatelstwa. Przykładem tego ostatniego może być odejście przez Niemcy w 2000 r. od posługiwania się ius sanguinis na rzecz modelu zbliżonego do ius soli ${ }^{53}$.

Istotne jest, że nawet zwolennicy liberalnej polityki imigracyjnej są świadomi, znanego także utylitarystom i komunitarystom, ryzyka związanego $\mathrm{z}$ otwarciem granic. Utylitaryści podnoszą, że może ono uniemożliwić jakąkolwiek racjonalną dystrybucję na

49 Por. na ten temat: K. Pędziwiatr, Od islamu imigrantów do islamu obywateli: muzułmanie $w$ krajach Europy Zachodniej, Kraków 2007, s. 25-27. Status gastarbeiterów jako imigrantów można zasadnie kwestionować, biorąc pod uwagę, iż zgodnie ze stosownymi, międzyrządowymi umowami mieli oni po wygaśnięciu umów o pracę wracać do ojczyzny.

${ }^{50}$ L. Henkin, op. cit., s. 1020.

51 Rozważane są oczywiście możliwości rozciągania argumentacji utylitarystycznej i komunitarystycznej na płaszczyznę globalną (por. M. Soniewicka, Granice sprawiedliwości...), w tym miejscu odnoszę je jedynie do polityki imigracyjnej, a więc zakładającej perspektywę wewnątrzpaństwową.

52 Sformułowanie Walzera w: Sfery sprawiedliwości..., s. 92 n.

53 K. Banerjee, op. cit., s. 8. 
poziomie wewnętrznym, a ta jest przecież warunkiem dystrybucji na poziomie globalnym $^{54}$, i odwrotnie - prowadzenie globalnej polityki dystrybucyjnej nie zatrzyma migracji, zawsze będą istnieć miejsca, w których warto żyć bardziej niż w innych ${ }^{55}$. Komunitaryści z kolei zwracają uwagę na mogący być efektem nieograniczonej imigracji zanik więzi wspólnotowych i patriotyzmu, niezbędnych do utrzymania spójności wspólnoty ${ }^{56}$. Wskazują na potrzebę istnienia pewnego etosu społecznego obywateli warunkującego prawidłowe funkcjonowanie państwa.

Zastrzeżenia te, po uznaniu ich słuszności, powodują konieczność opracowania dobrze uzasadnionych i zgodnych co najmniej z wymogami praw człowieka reguł polityki imigracyjnej i naturalizacyjnej. Moim zdaniem pomocne w tym celu, a przynajmniej godne rozważenia, mogą być wywodzące się z ekonomicznej analizy prawa konstatacje dotyczące tzw. dylematu „gapowicza”.

\section{Obywatel versus gapowicz}

W dotychczasowych rozważaniach używałem obywatelstwa jako synonimu uprawnień gwarantowanych przez państwo osobom posiadającym ten status. Za komunitarystami wskazałem jednak, iż dla utrzymania stanu, w którym obywatelom gwarantowane są pewne uprawnienia, niezbędny jest etos społeczny, cnoty obywatelskie pozwalające zachować sprawne i wydolne państwo. Obywatelem będzie więc osoba zaangażowana w podtrzymywanie systemu, którego jest jednocześnie beneficjentem, osoba wspierająca dobro wspólne. Opozycyjną do tej postawy będzie ta prezentowana przez „gapowicza”, tj. osobę, „która chce korzystać z danego dobra, ale uchyla się od zapłacenia należnej części kosztów związanych z jego wytworzeniem" ${ }^{37}$. Z konstrukcji gapowicza najczęściej korzysta się, dokonując analiz ekonomicznych związanych $\mathrm{z}$ wytworzeniem lub utrzymaniem dóbr materialnych (infrastruktura, środowisko naturalne). Jest to perspektywa odmienna od tej właściwej zwolennikom globalnej sprawiedliwości, oparta na stanowiącym podstawę wnioskowań ekonomicznych „racjonalnym egoizmie” jednostki. Republikanie czy komunitaryści z powodzeniem przenoszą konstrukcję gapowicza na problem wytwarzania i podtrzymywania dóbr idealnych, takich jak instytucje demokratyczne czy prawa człowieka ${ }^{58}$.

Zasadniczą, narzucającą się odnośnie do konstrukcji gapowicza wątpliwością, zwłaszcza w odniesieniu do dóbr idealnych, jest konieczność istnienia konsensusu w zakresie tego, co jest „dobrem”. Brak tego konsensusu powoduje automatycznie brak matrycy pozwalającej na dokonywanie jakichkolwiek wartościowań i ocen. Odpowiadając na tę wątpliwość, wskazać należy na szeroki zakres uznania dla takich wartości, jak demokracja

54 E.B. Foley, op. cit., s. 260.

55 M. Walzer, Sfery sprawiedliwości..., s. 86.

56 Ibidem, s. 105. Obydwie linie argumentacji obecne są już u Henry'ego Sidgwicka, por. M. Walzer, Sfery sprawiedliwości..., s. 70.

57 J. Stelmach, B. Brożek, W. Załuski, Dziesięć wykładów o ekonomii prawa, Warszawa 2007, s. 56.

58 W. Kymlicka, op. cit., s. 365; L. Morawski, op. cit., s. 25 n. 
czy prawa człowieka (przynajmniej w ich wersji akceptującej różnice kulturowe i lokalne tradycje). Przyjmując perspektywę globalnej sprawiedliwości, odpowiedzieć można, że istnienie tych dóbr w pewnych państwach jest warunkiem sine qua non udzielania przez nie pomocy innym. Ponadto zachowanie tych dóbr jest konieczne do powstania bardziej złożonych dóbr i wartości. Kolejne zarzuty są już bardziej szczegółowe i zawierają się w pytaniach o to, jak przełożyć konstrukcję gapowicza na treść konkretnych norm prawnych. Przytoczmy kilka z tych wątpliwości. Po pierwsze - co z osobami, które już zamieszkują dane państwo i przypominają bardziej gapowiczów niż obywateli? Czy uzasadniona jest odmowa wstępu do kraju imigrantom w sytuacji, gdy tolerujemy obecność gapowiczów wewnątrz kraju? Jak odróżnić gapowicza od osoby mogącej zostać zaangażowanym obywatelem? Oczywistym jest, iż ocena musi być indywidualna i nie może opierać się na generalizacjach, ale czy jest inna metoda niż zezwolenie na zamieszkanie w państwie na „okres próbny” i ewentualne wydalenie bądź odmowa przyznania obywatelstwa (które coraz częściej przestaje być warunkiem korzystania z szeregu uprawnień)?

Uważam, że mimo tych wątpliwości model gapowicza jest atrakcyjnym narzędziem pozwalającym w obiektywny, komplementarny względem ideałów globalnej sprawiedliwości sposób uzasadnić i doprecyzować reguły polityki imigracyjnej w sytuacji, gdy realizacja postulatów sprawiedliwości sprowadza się do liberalnej dystrybucji przynależności, otwartej polityki migracyjnej. Odwołanie do konstrukcji gapowicza opiera się na założeniu, że państwa przyjmujące będą w stanie pomagać przyjmowanym jedynie w sytuacji, gdy w ich granicach zostanie utrzymany porządek oparty o zasady demokracji, praw człowieka, ewentualnie państwa dobrobytu. To z kolei wymaga zapobiegania gapowiczostwu.

\section{Podsumowanie}

Do tej pory wskazywałem, że modelem polityki imigracyjnej spójnym z ideałami globalnej sprawiedliwości jest model liberalno-uprawnieniowy. Pojawiło się także zastrzeżenie, że polityka taka nie powinna być jednak kierowana do potencjalnych gapowiczów. Pozwalałoby to zachować ideały sprawiedliwości przy jednoczesnej trosce o najszerzej pojmowany dobrobyt obywateli i utrzymanie możliwości dalszego funkcjonowania tej polityki. Odnośnie do tych konstatacji może pojawić się zarzut, że nie uwzględniają one odmienności sytuacji uchodźców, czyli osób, które nie chcą korzystać z ochrony gwarantowanej przez kraj pochodzenia (bądź tej ochrony nie otrzymują), na skutek obawy przed prześladowaniem w tym kraju z powodu rasy, religii, przekonań politycznych lub przynależności do określonej grupy społecznej j9, od pozostałych imigrantów. Jest to istotny problem. Okazanie pomocy osobom prześladowanym z pewnością należy traktować jako jeden ze środków realizacji minimalnych standardów, które nie muszą być przecież wcale naruszane w kraju pochodzenia innych kategorii migrantów, co z ko-

59 Ustawa z dnia 13 czerwca 2003 r. o udzielaniu cudzoziemcom ochrony na terytorium Rzeczypospolitej Polskiej (Dz.U. z 2012 r. poz. 680 t.j.), art. 13 ust. 1. 
lei stawia pod znakiem zapytania nasze obowiązki względem nich. Będzie to jednak na ogół problem tego, co uznajemy za minimalny standard (wyłącznie prawa polityczne czy również prawo do pewnego „minimum socjalnego”?). Niezależnie od tego, w mojej ocenie, zastrzeżenia wyprowadzone z konstrukcji gapowicza zachowują swoją aktualność w kontekście uchodźców. W tym kierunku zmierzają chociażby przepisy ustawy o udzielaniu cudzoziemcom ochrony na terytorium RP, stwierdzające m.in., że

cudzoziemcowi odmawia się nadania statusu uchodźcy, jeżeli: [...] istnieją poważne podstawy, aby sądzić, że: [...] jest winny działań sprzecznych z celami i zasadami Narodów Zjednoczonych określonymi w Preambule i art. 1 i 2 Karty Narodów Zjednoczonych ${ }^{60}$.

Zachowany jest zatem warunek, że nie gwarantuje się minimalnych standardów osobom, które same ich nie przestrzegają. Poza tym oczywistym jest, że samo nadanie statusu uchodźcy ma niewiele wspólnego z uzyskaniem obywatelstwa. Naturalizacja może być w mojej ocenie obarczona bardziej restrykcyjnymi warunkami, wynikającymi z ryzyka "gapowiczostwa" imigrantów. Walzer ujmuje to w następujący sposób:

proces samostanowienia, poprzez który państwo demokratyczne kształtuje swoje życie wewnętrzne, musi być otwarty - i to na równi otwarty - dla wszystkich mężczyzn i kobiet, którzy mieszkają na jego terytorium, są zatrudnieni w lokalnej gospodarce i podlegają prawu lokalnemu ${ }^{61}$.

Przełóżmy teraz powyższe rozważania na obecną sytuację w UE. Po pierwsze, trudno mówić o jakimś górnym pułapie zdolności poszczególnych państw do przyjęcia imigrantów. We współczesnej Europie na bok można odłożyć zmory maltuzjanizmu, chociaż pojawić się mogą pewne problemy techniczne $\mathrm{z}$ osiedlaniem migrantów w pierwszym okresie po ich przybyciu. Mogą się również pojawić problemy z integracją w kolejnych pokoleniach. Właśnie dlatego istotniejszy jest warunek ,jakościowy”, opierający się na tym, że przyjmujemy ludzi gotowych akceptować zasady demokracji, praw człowieka oraz skłonnych do wnoszenia własnej pracy w utrzymanie welfare state, by umożliwić dalsze funkcjonowanie państwa opartego na tych zasadach i gotowego na udzielanie pomocy innym. Odwołując się do metafory autorstwa Garretta Hardina, który twierdzi, że w razie posiadania miejsc wolnych $\mathrm{w}$ łodzi ratunkowej nie powinniśmy wpuszczać osób spoza łodzi, bo może to ją zatopić ${ }^{62}$, chcę powiedzieć, że bardziej istotne jest, by wpuszczone osoby wiosłowały na równi z wcześniej obecnymi, niż to ile nowych osób zostanie przyjętych. Wobec tego chybione są moim zdaniem argumenty entuzjastów przyjmowania emigrantów (chociaż, z zachowaniem wyżej opisanego „ale”, bliski jest mi ich wniosek) wskazujące na niewielką „liczbę” przybyszów, do której przyjęcia miała zostać zobowiązana Polska. $\mathrm{Z}$ argumentów tych wynika, że nasze zobowiązanie do pomocy miałoby inny kształt $\mathrm{w}$ razie zmiany liczby imigrantów. Po drugie, decydując się na wpuszczenie imigrantów (w czym zabrakło konsekwencji), winniśmy umożliwić im uzyskanie obywatelstwa państw przyjmujących, oczywiście również po weryfikacji, czy nie są gapowiczami. Ocena gapowiczostwa nie będzie łatwa, sformułowanie właściwych procedur z pewnością będzie wyzwaniem dla prawodawcy. Obecnie trudno jest przesą-

\footnotetext{
${ }^{60}$ Ibidem, art. 19 ust. 1 pkt 3) lit. b).

61 M. Walzer, Sfery sprawiedliwości..., s. 103.

62 Por. M. Soniewicka, Granice sprawiedliwości..., s. 117.
} 
dzać o losie i intencjach rzesz imigrantów, pewną wskazówkę odnośnie do ich ewentualnego „gapowiczostwa” dają jednak kierunki migracji wewnątrz UE. Celem są „państwa dobrobytu": Niemcy, Austria i państwa skandynawskie.

\section{Bibliografia}

Banerjee K., Toward post-national membership? Tensions and transformation in German and EU citizenship, „Journal of International Law and International Relations” 10, 2014.

Brock G., Basic liberties and global justice, „Canadian Journal of Law and Jurisprudence” 19, 2006, nr 2.

Dower N., Nędza na świecie, [w:] Przewodnik po etyce, red. P. Singer, Książka i Wiedza, Warszawa 2009.

Foley E.B., The elusive quest for global justice, „Fordham Law Review” 66, 1997-1998.

Garcia F.J., Three takes on global justice, „University of La Verne Law Review” 31, 2009-2010.

Gray J., Al-Kaida i korzenie nowoczesności, Fundacja Aletheia, Warszawa 2006.

Henkin L., An immigration policy for just society?, „San Diego Law Review” 31, 1994.

Kuniński M., Sprawiedliwość globalna: szlachetny ideał czy rzetelna teoria?, „Diametros” grudzień $2010, \mathrm{nr} 26$.

Kymlicka W., Współczesna filozofia polityczna, Fundacja Aletheia, Warszawa 2009.

Mandle J., Globalna sprawiedliwość, Sic!, Warszawa 2009.

Morawski L., Suwerenność i prawo międzynarodowe - od prawa państw do prawa ludów, „Forum Prawnicze" styczeń 2011, nr 1 (3).

Pędziwiatr K., Od islamu imigrantów do islamu obywateli: muzułmanie w krajach Europy Zachodniej, Zakład Wydawniczy Nomos, Kraków 2007.

Rawls J., Liberalizm polityczny, Wydawnictwo Naukowe PWN, Warszawa 1998.

Rawls J., Prawo ludów, Fundacja Aletheia, Warszawa 2001.

Rorty R., Filozofia jako polityka kulturalna, Czytelnik, Warszawa 2009.

Sadurski W., Teoria sprawiedliwości. Podstawowe zagadnienia, Wydawnictwo Naukowe PWN, Warszawa 1988. Sandel M., Sprawiedliwość. Jak postępować słusznie?, Kurhaus Publishing, Warszawa 2013.

Skrentny J.D., How to understand immigration policy, „Brown Journal of World Affairs” 20, 2013, nr 1.

Soniewicka M., Granice sprawiedliwości, sprawiedliwość ponad granicami, Wolters Kluwer Polska, Warszawa 2010.

Soniewicka M., Sprawiedliwość globalna — przegląd wybranych zagadnień, http://www.incet.uj.edu.pl/dzialy.php? $1=\mathrm{pl} \& \mathrm{p}=32 \& \mathrm{i}=1 \& \mathrm{~m}=22 \& \mathrm{z}=0 \& \mathrm{n}=2 \& \mathrm{k}=13$ (dostęp: 12 września 2015).

Stelmach J., Brożek B., Załuski W., Dziesięć wykładów o ekonomii prawa, Wolters Kluwer Polska, Warszawa 2007.

Ustawa z dnia 13 czerwca 2003 r. o udzielaniu cudzoziemcom ochrony na terytorium Rzeczypospolitej Polskiej, Dz.U. z 2012 r. poz. 690 t.j.

Vernon R., Contractualism and global justice: The iteration provisio, „Canadian Journal of Law and Jurisprudence" 19, 2006, nr 2.

Walzer M., Sfery sprawiedliwości. Obrona pluralizmu i równości, Wydawnictwo Uniwersytetu Warszawskiego, Warszawa 2007.

Walzer M., Spór o wojnę, Muza, Warszawa 2006.

Zanetti V., Equality or a minimal standard in global justice?, „European Journal of Law Reform” 6, 2004, nr 3-4. 


\section{Global justice and the problem of immigration}

Keywords: global justice, liberalism, communitarianism, immigration, free-rider problem

Summary

Modern legal philosophy provides us with two main types of global justice theories. Distributive or egalitarian theories claim that justice requires striving to achieve the global equality from us not only in legal but also economic dimension. On the other hand, there are many theories focusing on providing and keeping only „minimal standard” (i.e. human rights) and questioning the global equality as an ideal. In the article I investigate which type of theories describes contemporary international relations in the most accurate way (claiming that "minimal standard” theory does it) and I also wonder which type is more legitimate. In my opinion, considerations devoted to the question of global justice give us a well-established background for further studies on immigration policy, especially in the context of recent EU frontiers incidents. 